\title{
Protective Effect of Tribulus terrestris Hydroalcoholic Extract against Cisplatin-Induced Cytotoxicity on Sperm Parameters in Male Mice
}

\author{
Efecto Protector del Extracto Hidroalcohólico de Tribulus terrestris contra la Citotoxicidad \\ Inducida por Cisplatino sobre Parámetros Espermáticos en Ratones Macho
}

Zahra Keshtmand ${ }^{*, * *}$; Shahrbanoo Oryan ${ }^{* *}$; Ali Ghanbari ${ }^{* * *} \&$ Mozafar Khazaei*** $^{* * *}$

KESHTMAND, Z.; ORYAN, S.; GHANBARI, A. \& KHAZAEI, M. Protective effect of Tribulus terrestris hydroalcoholic extract against cisplatin-induced cytotoxicity on sperm parameters in male mice. Int. J. Morphol., 32(2):551-557, 2014.

SUMMARY: Cisplatin is an anti-cancer drug used in chemotherapy. One of the limiting side effects of cisplatin is decreasing genital gland function, azoospermia and oligospermia. Tribulus terrestris has been used as an aphrodisiac. The present study amid to investigate protective effect of Tribulus terrestris hydroalcoholic extract against cisplatin-induced cytotoxicity on sperm parameters in mice. Male adult mice $(n=30)$ were divided into control and 4 experimental groups $(n=6)$. Control group received saline, first experimental group received cisplatin $(5.5 \mathrm{mg} / \mathrm{kg})$ and other three experimental groups received cisplatin $(5.5 \mathrm{mg} / \mathrm{kg})$ and different doses of hydroalcoholic extact of Tribulus terrestris (100, 300 and $500 \mathrm{mg} / \mathrm{kg} / \mathrm{i} . \mathrm{p})$ respectively. On the day after the last injection, blood samples were collected for serum Nitric oxide (NO) assay. Also weights of body and testis, sperm parameters and seminiferous tubules diameter were assessed. Data analysis was performed using one-way ANOVA followed by Tukeys' test. The results showed that cisplatin lead to a reduction in the weight of body and testes, sperm parameters and increased level serum of NO significantly compared to the control group $(\mathrm{P}<0.05)$, while in treated groups with Tribulus terrestris, the weights of body and testes, sperm parameters, seminiferous tubules diameter were significantly higher compared with cisplatin group $(\mathrm{P}<0.05)$, but serum level of NO did not show significant differences. The study demonstrates that extract of Tribulus terrestris could protective effect against cisplatin- induced cytotoxicity on sperm parameters that may be related to the presence of antioxidant components acting via a multitude of central and peripheral mechanisms.

KEY WORDS: Cisplatin; Tribulus terrestris; Sperm parameters; Mice.

\section{INTRODUCTION}

Cisplatin (cis-[Pt(II)(NH(3))(2) Cl(2)]([PtCl $\left.{ }_{2}\left(\mathrm{NH}_{3}\right) 2\right]$ or CDDP) is one of the most potent chemotherapy drugs widely used for cancer treatment. Clinical success of CDDP and its derivatives determined considerable effort to develop other effective metal-based anti-cancer compounds. However, its use is limited due to side effects in normal tissues (Che et al., 2010). Hence the exposure to chemotherapeutic drugs was suggested by many recent studies as one of the possible causes of the significant decline in the sperm count for the past 50 years (Kishore et al., 2009). Cisplatin toxicity is occurred by increased production of reactive oxygen species (ROS) and decreased production of antioxidants (Chirino \& PedrazaChaverri, 2009). The formation of ROS depends on the concentration of CDDP and the duration of exposure (Brozovic et al., 2010). ROS might reduce the capacities of the cell by inducing lipid peroxidation, depletion of the sulfhydryl groups, altered signal transduction pathways, calcium homeostasis and DNA damage (Desoize, 2006). Moreover, it was reported that the toxicity caused by cisplatin in the tissues was closely related to increased lipid peroxidation, a process which leads to functional impairment of spermatozoa (Wozniak et al., 2004).

Nitric oxide (NO) is another reactive free radical with an important modulatory effect on cellular functions. It has been implicated that $\mathrm{NO}$ is involved in numerous physiological, pharmacological and pathological processes in both female and male reproductive tracts (Rosselli et al., 1995). It has been shown that sensitivity to the cytotoxic activity of cisplatin was increased dramatically when tissue culture media was saturated with NO gas (Wink et al., 1997). More recent analysis of NO specifically designed to interact

\footnotetext{
* Department of Biology, Science and Research Branch, Islamic Azad University, Tehran, Iran.

${ }^{* *}$ Faculty of Biological Sciences, Kharazmi University, Tehran, Iran.

****Fertility and Infertility Research Center, Kermanshah University of Medical Sciences, Kermanshah, Iran.
} 
with glutathione S-transferase (GST) also demonstrated synergism with cisplatin, an effect attributed to increased cellular accumulation of cisplatin and potentially activation of the mitogen-activated protein kinase (MAPK) pathway (Liu et al., 2004).

Tribulus terrestris (TT) is a perennial creeping herb that is broadly distributed in Mediterranean, subtropical. It has been used since ancient times in traditional folk medicine as aphrodisiac and other ailments and also been shown to induce aphrodisiac on rats (Gauthaman \& Ganesan, 2008). TT improves some aspects of male sexual behavior and enhances spermatogenesis in rats (Gauthaman \& Ganesan). Additionally, clinical data indicate the stimulatory effects of TT on sperm quantity and quality and improved sexual response in men. Increased androgen levels have also been reported following $\mathrm{T}$ terrestris administration in nonhuman primates, rats, and rabbits (Gauthaman \& Ganesan; El-Tantawy et al., 2007), but most of these effects were short-lived and showed no clear dose-response relationship. In addition, there is no consensus on the mechanism underlying the effects of TT on sexual performance and spermatogenesis.

The treatment of castrated rats with a TT extract was previously shown to increase the weight of prostate and intracavernous pressure (ICP). Improved sexual behavior was also detected, as evidenced by an increase in mounting frequency. However, much debate surrounds the possible mechanisms of action and the therapeutic applications of TT extracts.

Increased androgen levels have also been reported following TT administration in nonhuman primates, rats, and rabbits (El-Tantawy et al.). Because TT has been used to improve sexual function in various regions of the world and occurrence of some controversies in experimental studies. The aim of the present work was to find protective effect of TT extract on cisplatin-induced cytotoxicity on sperm parameters, NO level, testis tissue and weight in mice.

\section{MATERIAL AND METHOD}

Preparation of plant extract. T. terrestris was purchased from a traditional medicine center and identified and authenticated by a botanist. TT ( $400 \mathrm{~g}$ ) were powdered and added to $800 \mathrm{cc}$ of $70 \%$ ethanol and were left to macerate at room temperature for 4 hours. Then, the soaked seeds were extracted by percolation method and the obtained extract was concentrated in the vacuum and was dried in the flat surface (Khazaei \& Salehi, 2006). The weight of the obtained extract was $6.5 \mathrm{~g}$. The extract was dissolved in distilled water and was immediately administered intraperitoneally (IP) to mice, expressed as mg of extract per $\mathrm{kg}$ of body weight and injection administered from day one for 4 days.

Drug. Cisplatin (EBEWE Pharma, Unterach, Austria) was dissolved in saline in darkness, 10-15 min before use and an intraperitoneal injection $(5.5 \mathrm{mg} / \mathrm{kg})$ was given at the one day of experiment (Bagnis et al., 2001).

Animals-inbred. Thirty male Balb/c mice with weight of 25$30 \mathrm{~g}$ were used. Animals were kept at a temperature of $22 \pm 2^{\circ} \mathrm{C}$, under controlled environmental conditions, 12-hour light-dark cycles and fed standard pellet chow and water ad libitum. All experiment procedures were conducted in accord with the principles for the care and use of laboratory animals in research and approved by local ethics committee of our university.

Experiment protocol. After a quarantine period of 7 days, 30 mice were randomly divided into five groups $(n=6)$. Group I was used as control and received saline IP. Group II received only cisplatin in single dose of $5.5 \mathrm{mg} / \mathrm{kg} / \mathrm{IP}$. daily (E1). Group III received cisplatin $+100 \mathrm{mg} / \mathrm{kg}$ extract of TT (E2). Group IV received cisplatin $+300 \mathrm{mg} / \mathrm{kg}$ extract of TT (E3). Group V received cisplatin $+500 \mathrm{mg} / \mathrm{kg}$ extract of TT (E4). Experimental groups were treated over period of 4 consecutive days.

Assessment of NO level. Blood was taken from heart and preserved in the temperature of $37^{\circ} \mathrm{C}$ for 30 minutes and was centrifuged $(3000 \mathrm{~g})$ for 30 minutes. The serum was collected and preserved in $-20^{\circ} \mathrm{C}$ until measuring the serum level of NO was performed by Griess assay.

Analysis sperm parameteres. The left cauda epididymis was separated and chopped in DMEM/F12 containing 5\% FBS which had been balanced in the incubator previously; it was then placed in incubator with the temperature of $37^{\circ} \mathrm{C}$ and $5 \% \mathrm{CO}_{2}$. The prepared suspension was used for the analysis of sperm parameters including: motility, count and morphology. Sperm motility was divided into four levels (Mehrabi Nasab et al., 2010): (0): without motility, (I): minor in situ motility. (II): circumferential motility and (III): progressive motility. Also the diluted solution was transferred into each chamber of Neubauer hemocytometer and sperm heads manually counted under a microscope and data were expressed as the number of sperm per ml (Momeni et al., 2009). For the assessment of viability, we used eosin $Y$ staining that discriminate live sperm from dead sperm by staining cytoplasm of cell. We counted at least 200 sperm for each animal and discriminate live sperm that was not stained and dead sperm that was red (Cao et al., 2011). To examine sperm morphology, smear was prepared from the samples and was stained by Papanicolaou method (Zare et al., 2010). 
Histopathological Examination. Testes were dissected immediately and preserved in $10 \%$ buffered formaldehyde for further histophatological examination. Tissue samples were embedded in paraffin and $5 \mu \mathrm{m}$ sections were cut a rotary microtome and stained with hematoxylin and eosin (H\&E), and examined by light microscopy at X40. Diameter of seminiferous tubules was measured by Motic camera and software (AE3; motic S.L.C. Barcelona, Spain). The mean seminiferous tubule diameter in micrometers was determined for each testis and examined by light microscopy at $¥ 40$, totaling 200 seminiferous tubule sections per testis.

Statistical analysis. The data were analyzed by spss16 (SPSS Inc, Chicago, Illinois) and expressed as means \pm SE. Statistical significant difference was determined by one way analysis of variance (ANOVA) followed by Tukey's post hoc test for multiple comparison. Probability values $(\mathrm{P})$ less than 0.05 were considered to be statistically significant.

\section{RESULTS}

The mean weights of body and testis had significantly decreased in E1 in comparison with control group $(\mathrm{P}=0.037)$ but in E3 group increased significantly in comparison with $\mathrm{E} 1(\mathrm{P}=0.01)$ (Fig. 1A and $\mathrm{B})$. Testicular sections showed that the diameter of the seminiferous tubules were reduced in cisplatin treated mice $(\mathrm{P}=0.001)$ and seminiferous tubules diameter increased significantly $(\mathrm{P}=0.001)$ in $\mathrm{E} 3$ group in comparison with E1 group (Figs. 1C, 2).
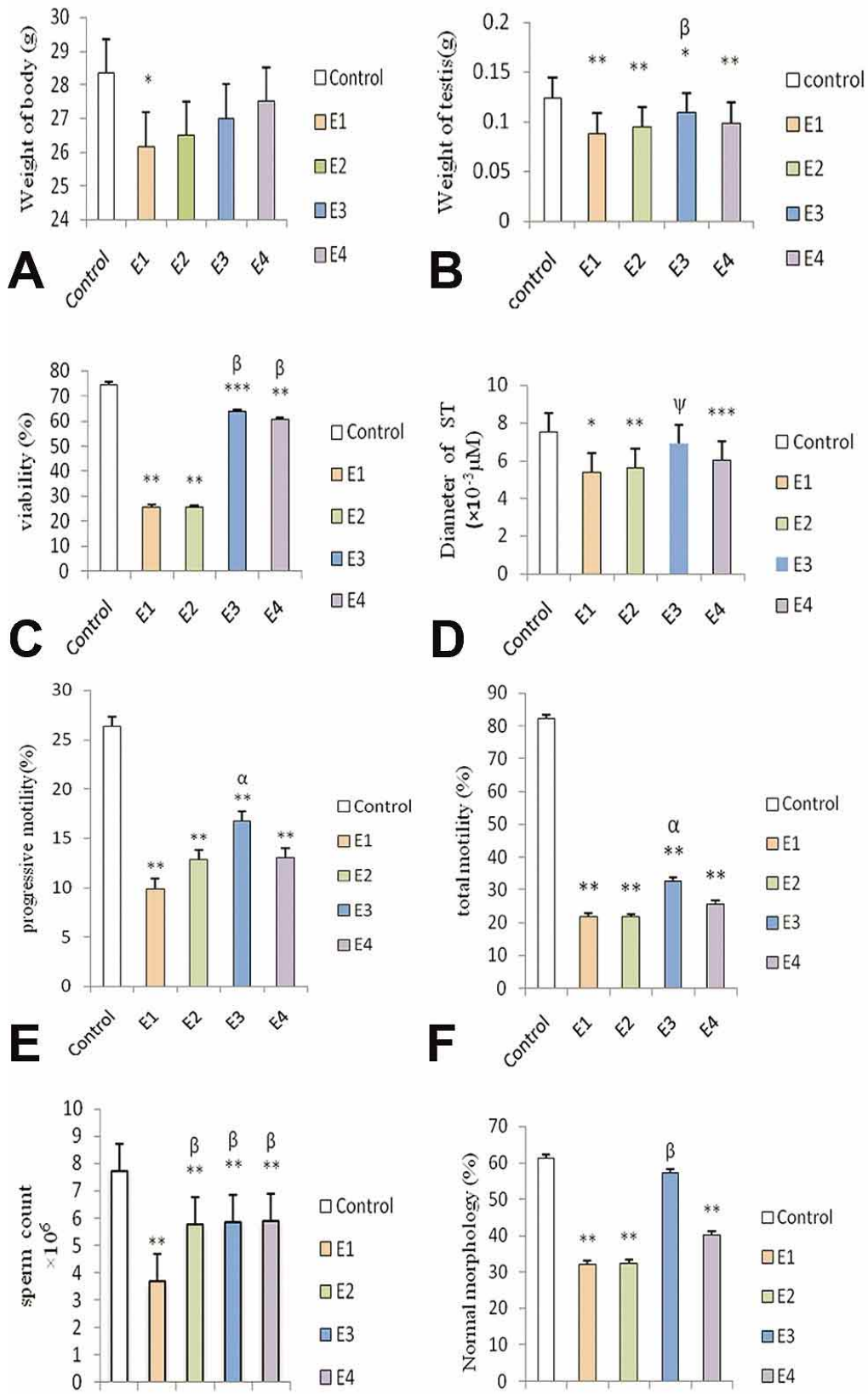

$\mathbf{G} 0^{x^{2}} \Leftrightarrow \Leftrightarrow$
Fig. 1. The effect of toxic dose of cisplatin $(5.5 \mathrm{mg} / \mathrm{kg})$ and different doses of T. terrestris on A: body weight, B: weight of testis, C: diameter of seminiferous tubules, D: viability sperm E: total motility of sperm F: progressive motility of sperm G: sperm count, H: sperm morphology, I: serum level of NO. The groups (X axis) are Control: not treated, E1: Cis $(5.5 \mathrm{mg} / \mathrm{kg}), \mathrm{E} 2$ : Cis + TT extract $(100 \mathrm{mg} / \mathrm{kg}), \mathrm{E} 3$ : Cis + TT extract (300 $\mathrm{mg} / \mathrm{kg}), \mathrm{E} 4: \mathrm{Cis}+\mathrm{TT}$ extract $(500 \mathrm{mg} / \mathrm{kg})$. Values $=$ Mean \pm SE. $* \mathrm{P}<0.05$ compared to the control group. $* * \mathrm{P}<0.01$ compared to the control group. $* * * \mathrm{P}<0.001$ compared to the control group. $\mathrm{a}=\mathrm{P}<0.05$ compared to the cisplatin group. $\mathrm{b}=\mathrm{P}<0.01$ compared to the cisplatin group. $\mathrm{y}=\mathrm{P}<0.001$ compared to the cisplatin group. 
The sperm viability showed a significant increase in the sperm viability in $\mathrm{E} 3(\mathrm{P}=0.01)$ and $\mathrm{E} 4$ groups $(\mathrm{P}=0.01)$ as compared to the E1group ( $\mathrm{p}=0.01$ ) (Fig. 1D). Motility analysis of sperms indicated that the total motility increased in $\mathrm{E} 4$ group $(\mathrm{P}=0.01)$ while it was decreased in $\mathrm{E}$ 1 group $(\mathrm{P}=0.01)$ (Fig. 1E). This analysis also confirmed that percentage of progressively motile sperm was increased in $\mathrm{E} 4$ group $(\mathrm{P}=0.042)$ (Fig. 1F).

According to statistical analysis count of sperm in $\mathrm{E} 2, \mathrm{E} 3$ and $\mathrm{E} 4$ groups in comparison with cisplatin group had significant increase ( $\mathrm{P}=0.01$ ) (Fig. 1G). The data showed that percentage of normal sperm was decrease in E1 group $(\mathrm{P}=0.01)$, while it was increased in $\mathrm{E} 4$ group $(\mathrm{P}=0.01)$ in comparison to E1 group (Fig. 1H). The sperm morphologies are shown in Figure 2. They included sperm normal shape and abnormal shapes (without tail, without head, without hook and defective head sperm). Also the mean serum level of NO in experimental groups was compared statistically with control group. Serum level of NO in E1 group was increased $(\mathrm{P}=0.05)$, while in $\mathrm{E} 2$, $\mathrm{E} 3$ and $\mathrm{E} 4$ groups, it decreased without significant difference $(\mathrm{P}>0.05)$ (Fig. 1I).

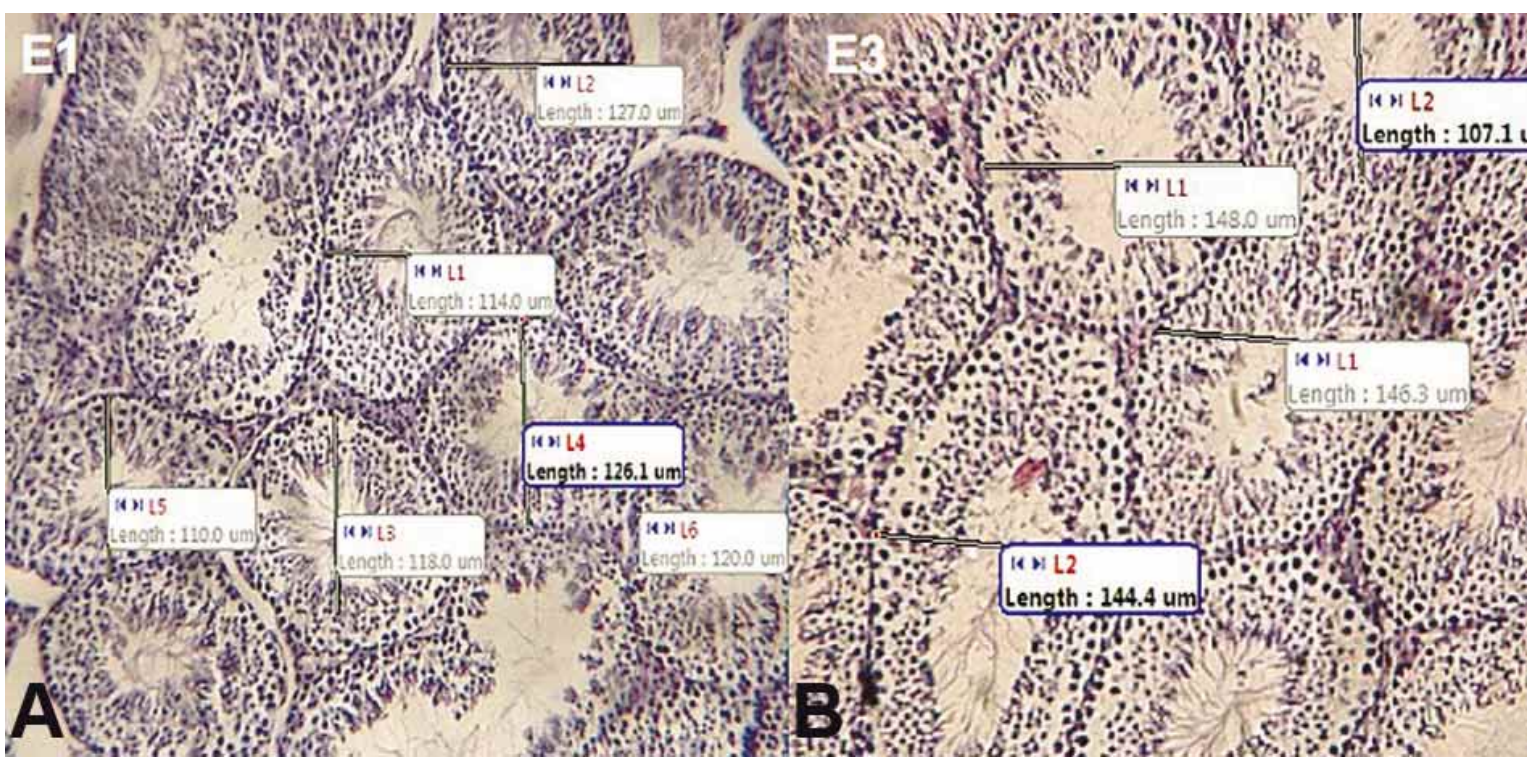

Fig. 2. Photomicrograph of seminiferous tubules in (A): Cisplatin group (5.5 mg/kg);(B): experimental group that received dose of $300 \mathrm{mg} / \mathrm{kg}$ extract of T. terrestris with cisplatin $(5.5 \mathrm{~g} / \mathrm{kg})$. Photos represent X400 magnification, H\&E staining.

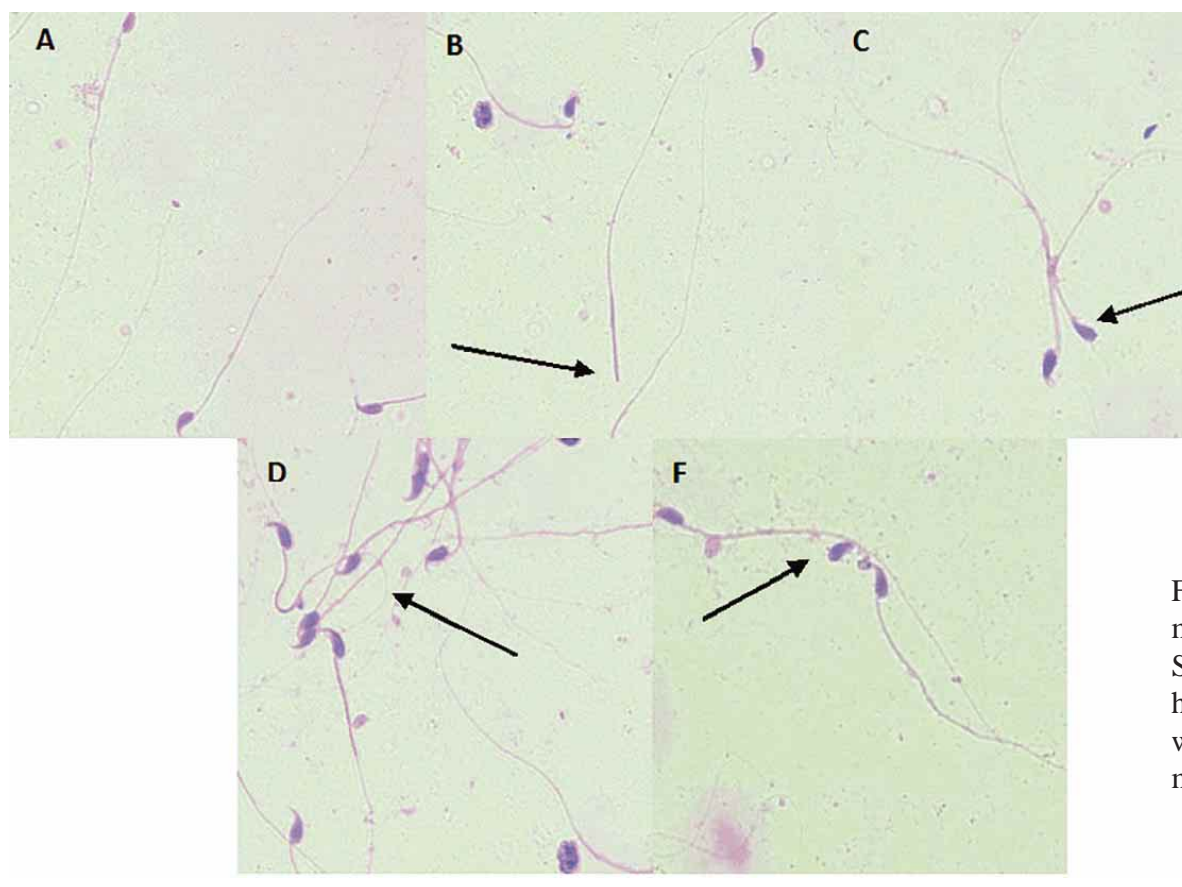

Fig. 3. Photomicrography of sperm morphologies. $\mathrm{A}=$ Normal sperm, $\mathrm{B}=$ Sperm without head, $\mathrm{C}=$ Sperm without hook, $\mathrm{D}=$ Defective head sperm, $\mathrm{F}=$ Sperm without tail. Photos represent $¥ 400$ magnification, staining Papanicolaou. 


\section{DISCUSSION}

In the present study, the protective effect of TT hydroalcoholic extract against cisplatin-induced cytotoxicity in mice was evaluated. The results showed a significant decline in the weight of animals treated with cisplatin. These data support other studies that indicated reductions in body weight could be attributable to toxic side effect of chemotherapeutic drugs and it suggests that TT reliefs the adverse effects of cisplatin (Yun et al., 2008). The present study also showed histological damage in testis of mice after 4 days of injection of one cytotoxic dose of cisplatin. There are many ways to protect toxicity of chemotherapeutic drugs. Hormonal therapy is a method to enhance recovery of spermatogenesis in chemotherapy treated animals. For this propose GnRH analogue Zoladex (Ward et al., 1990), testosterone and oestradiol (Kurdoglu et al., 1994), GnRH and the anti-androgen flutamide were applied before and during the period of treatment of animal with chemoradiotherapy.

Oxidative stress is harmful to sperm function and a significant factor in the etiology of male infertility (Makker et al., 2009). In addition, oxidative stress impairs male fertility by changing the cell function like sperm motility (Makker et al.), increase in DNA damage by induction of gene mutations, DNA denaturation, base pair oxidation and DNA fragmentation.

Many factors lead to the sperm abnormality especially sperm without head. Lipid peroxidation and accumulation of free radicals cause morphological damage of sperm (Scibona et al., 1994).

Protective effect of TT extract against cisplatin -induce cytotoxicity on reproductive parameters can be explained on the basis that the plant contains many materials which act as a potent antioxidant which may protect sperm membrane against lipid peroxidation that leads to decrease the percentage of dead sperm and maintaining normal sperm morphology. The TT also contains many trace elements, these minerals especially $\mathrm{Ca}++$ is known to inhibit the enzyme phosphate diesterase, which prevents cAMP degradation and consequently increasing sperm motility and sperm hyperactivity (Nassar et al., 1998). The presence of zinc in the TT leads to improvement of the sperm count, motility and morphology, because it involved in hormone metabolism, RNA and DNA organization, protein synthesis, cell division biomembranes and nuclear chromatin stabilization (Wang et al., 1990).

On the other hand, the active chemical in TT is likely to be protodioscin (PTN) (Gauthaman \& Ganesan). The antioxidant activity of TT Flavonoids act as scavengers of various oxidizing species i.e. super oxide anion (O2-•), hydroxyl radical or peroxy radicals, they also act as quenchers of singlet oxygen (Das \& Pereira, 1990).

TT could be inducing protective effect by mimicking lipid peroxidation as a consequence of its antioxidant nature as that was shown previously (Das \& Pereira; Temraz et al., 2006). The demonstration that NO-donating compounds induce oxidative stress and initiate apoptosis (Gao et al., 2005).

Low concentrations of $\mathrm{NO}$ enhance the in vitro motility of hamster (Yeoman et al., 1998) and human spermatozoa (Lewis et al., 1996), whereas at higher concentrations NO inhibits the motility of mouse (Herrero et al., 1994) and human spermatozoa (Rosselli et al.). High concentrations of $\mathrm{NO}$ are also able to affect sperm viability, displaying a cytotoxic effect that is probably mediated by oxidative stress and lipid peroxidation of sperm membranes (Sikka et al., 2001).

In conclusion, the present study demonstrated that hydroalcoholic extract of TT may protect the testis tissue and sperm parameters against injury from cisplatin cytotoxicity. We propose that TT modulates oxidative stress. This may be via mechanism linked to redox signaling, though scavenging of ROS and the presence of flavonoids, saponins, lignans, protodioscin, alkaloids and antioxidant component acting through a multitude of central and peripheral pathways. Consequently, the sperm parameters improved by lacking the hazardous compound of $\mathrm{NO}$ in cisplatin treated animals, but it is controversial and needs to the more study.

\section{ACKNOWLEDGMENTS}

The authors thank the Kermanshah University of Medical Science research fund for providing us with financial support on this work by grant no. 9205 . There is no conflict of interest in this study.

KESHTMAND, Z.; ORYAN, S.; GHANBARI, A. \& KHAZAEI, M. Efecto protector del extracto hidroalcohólico de Tribulus terrestris contra la citotoxicidad inducida por cisplatino sobre parámetros espermáticos en ratones macho. Int. J. Morphol., 32(2):551-557, 2014.

RESUMEN: El cisplatino es un medicamento contra el cáncer utilizado en la quimioterapia. Uno de los efectos secundarios limitantes de cisplatino es la decreciente función glándular genital, azoospermia y oligospermia. Tribulus terrestris ha sido 
utilizado como un afrodisíaco. En el presente estudio se investiga el efecto protector del extracto hidroalcohólico de Tribulus terrestris (TT) contra la citotoxicidad inducida por cisplatino en los parámetros espermáticos en ratones. Ratones adultos machos ( $\mathrm{n}=$ 30) fueron divididos en 4 grupos control y experimentales $(n=6)$. En el grupo control se administró solución salina, el primer grupo experimental recibió cisplatino $(5,5 \mathrm{mg} / \mathrm{kg})$ mientras que otros tres grupos experimentales recibieron cisplatino $(5.5 \mathrm{mg} / \mathrm{kg})$ además de diferentes dosis de extracto hidroalcohólico de TT $(100,300$ y $500 \mathrm{mg} / \mathrm{kg} / \mathrm{IP}$ ) respectivamente. El día siguiente de la última inyección, se analizaron muestras de sangre para expresión de óxido nítrito $(\mathrm{ON})$. Además, fueron evaluados el peso del cuerpo y testículos, los parámetros espermáticos y el diámetro de los túbulos seminíferos. Los datos fueron analizados mediante análisis ANOVA y la prueba de Tukey. El uso de cisplatino causó reducción del peso corporal y testicular, parámetros espermáticos y aumento significativo de los valores de $\mathrm{ON}$ en comparación con el grupo control $(\mathrm{P}<0,05)$, mientras que los grupos tratados con TT, fue significativamente mayor el peso corporal y testicular, parámetros espermáticos y diámetro de los túbulos seminíferos en comparación al grupo tratado con cisplatino $(\mathrm{P}<0,05)$. No se observaron diferencias significativas en los valores ON. El extracto de TT puede tener un efecto protector frente a la citotoxicidad inducida por el cisplatino sobre los parámetros espermáticos, al estar relacionado a la presencia de componentes antioxidantes que actúan mediante mecanismos centrales y periféricos.

PALABRAS CLAVE: Cisplatino; Tribulus terrestris; Parámetros espermáticos; Ratones.

\section{REFERENCES}

Bagnis, C.; Beaufils, H.; Jacquiaud, C.; Adabra, Y.; Jouanneau, C.; Le Nahour, G.; Jaudon, M. C.; Bourbouze, R.; Jacobs, C. \& Deray, G. Erythropoietin enhances recovery after cisplatininduced acute renal failure in the rat. Nephrol. Dial. Transplant., 16(5):932-8, 2001.

Brozovic, A.; Ambriovic'-Ristov, A \& Osmak, M. The relationship between cisplatin-induced reactive oxygen species, glutathione, and BCL-2 and resistance to cisplatin. Crit. Rev. Toxicol., 40(4):347-59, 2010.

Cao, X. W.; Lin, K.; Li, C. Y. \& Yuan, C. W. A review of WHO Laboratory Manual for the Examination and Processing of Human Semen. $5^{\text {th }}$ ed. Zhonghua Nan Ke Xue, 17(12):105963, 2011.

Che, C. M. \& Siu, F. M. Metal complexes in medicine with a focus on enzyme inhibition. Curr. Opin. Chem. Biol., 14(2):255-61, 2010.

Chirino,Y. I. \& Pedraza-Chaverri, J. Role of oxidative and nitrosative stress in cisplatin-induced nephrotoxicity. Exp. Toxicol. Pathol., 61(3):223-42, 2009.
Das, N. P. \& Pereira, T. A. Effects of flavonoids on thermal autoxidation of palm oil: Structure-activity relationships. $J$. Am. Oil Chem. Soc., 67(4):255-8, 1990.

Desoize, B. Cancer and metals and metal compounds: part I-carcinogenesis. Crit. Rev. Oncol. Hematol., 42(1):1-3, 2002.

El-Tantawy, W. H.; Temraz, A. \& El-Gindi, O. D. Free serum testosterone level in male rats treated with Tribulus alatus extracts. Int. Braz. J. Urol., 33(4):554-8, 2007.

Gao, J.; Liu , X. \& Rigas, B. Nitric oxide-donating aspirin induces apoptosis in human colon cancer cells through induction of oxidative stress. Proc. Natl. Acad. Sci. USA, 102(47):1720712, 2005.

Gauthaman, K. \& Ganesan, A. P. The hormonal effects of Tribulus terrestris and its role in the management of male erectile dysfunction--an evaluation using primates, rabbit and rat. Phytomedicine, 15(1-2):44-54, 2008.

Herrero, M. B.; Cebral, E.; Boquet, M.; Viggiano, J. M.; Vitullo, A. \& Gimeno, M. A. Effect of nitric oxide on mouse sperm hyperactivation. Acta Physiol. Pharmacol. Ther. Latinoam., 44(3):65-9, 1994.

Kangasniemi, M.; Wilson, G.; Huhtaniemi, I. \& Meistrich, M. L. Protection against procarbazine-induced testicular damage by GnRH-agonist and antiandrogen treatment in the rat. Endocrinology, 136(8):3677-80, 1995.

Khazaei, M. \& Salehi, S. Protective effect of Falcaria vulgaris extract on ethanol- induced gastric ulcers in rat. Iran. J. Pharmacol. Ther., 5(1):43-46, 2006.

Kishore, R. Y. V.; Sreenivasula, R. P.; Shivalingam, M. R. \& Pravallika Gamini, C. N. N. S. Dose dependent alterations in epididymal sperm counts of cisplatin or carboplatin treated male Wistar rats. J. Pharm. Sci. Res., 1(4):167-72, 2009.

Kurdoglu, B.; Wilson, G.; Parchuri, N.; Ye, W. S. \& Meistrich, M. L. Protection from radiation-induced damage to spermatogenesis by hormone treatment. Radiat. Res., 139(1):97-102, 1994.

Lewis, S. E.; Donnelly, E. T.; Sterling, E. S.; Kennedy, M. S.; Thompson, W. \& Chakravarthy, U. Nitric oxide synthase and nitrite production in human spermatozoa: evidence that endogenous nitric oxide is beneficial to sperm motility. Mol. Hum. Reprod., 2(11):873-8, 1996.

Liu , J.; Li, C.; Qu, W.; Leslie, E.; Bonifant, C. L.; Buzard , G. S.; Saavedra, J. E.; Keefer, L. K. \& Waalkes, M. P. Nitric oxide prodrugs and metallochemotherapeutics: JS-K and CB-3-100 enhance arsenic and cisplatin cytolethality by increasing cellular accumulation. Mol. Cancer Ther., 3(6):709-14, 2004.

Makker, K.; Agarwal, A. \& Sharma, R. Oxidative stress \& male infertility. Indian J. Med. Res., 129(4):357-67, 2009. 
Mehrabi Nasab, E.; Khazaei, M. \& Khazaei, S. The effect of Pentylenetetrazol kindling induced epilepsy on hypogonad hormones and sperm parameters of rats. Arak Med. Univ. J., 12(4):105-12, 2010.

Momeni, H. R.; Soleimani Mehranjani, M.; Abnosi, M. H. \& Mahmoodi, M. Effects of vitamin E on sperm parameters and reproductive hormones in developing rats treated with para-nonylphenol. Iran. J. Reprod. Med., 7(3):111-6, 2009.

Nassar, A.; Mahony, M.; Blackmore, P.; Morshedi, M.; Ozgur, $\mathrm{K}$. \& Oehninger, S. Increase of intracellular calcium is not a cause of pentoxifylline-induced hyperactivated motility or acrosome reaction in human sperm. Fertil. Steril., 69(4):74854,1998

Rosselli, M.; Dubey, R. K.; Imthurn, B.; Macas, E. \& Keller, P. J. Effects of nitric oxide on human spermatozoa: evidence that nitric oxide decreases sperm motility and induces sperm toxicity. Hum. Reprod., 10(7):1786-90, 1995.

Scibona, M.; Meschini, P.; Capparelli, S.; Pecori, C.; Rossi, P. \& Menchini Fabris, G. F. L-arginine and male infertility. Minerva Urol. Nefrol., 46(4):251-3, 1994.

Sikka, S. C. Relative impact of oxidative stress on male reproductive function. Curr.Med. Chem., 8(7):851-62, 2001.

Temraz, A.; El Gindi, O. D.; Kadry, H. A.; De Tommasi, N. \&Braca, A. Steroidal saponins from the aerial parts of Tribulus alatus Del. Phytochemistry, 67(10):1011-8, 2006.

Wang, B.; Ma, L. \& Liu, T. 406 cases of angina pectoris in coronary heart disease treated with saponin of Tribulus terrestris. Zhong Xi Yi Jie HeZa Zhi, 10(2):85-7, 68, 1990.

Ward, J. A.; Robinson, J.; Furr, B. J.; Shalet, S. M. \& Morris, I. D. Protection of spermatogenesis in rats from the cytotoxic procarbazine by the depot formulation of Zoladex, a gonadotropin-releasing hormone agonist. Cancer Res., 50(3):568-74, 1990.

Wink, D. A.; Cook, J. A.; Christodoulou, D.; Krishna, M. C.; Pacelli, R.; Kim, S.; DeGraff, W.; Gamson, J.; Vodovotz, Y.; Russo, A. \& Mitchell, J. B. Nitric oxide and some nitric oxide donor compounds enhance the cytotoxicity of cisplatin. Nitric Oxide, 1(1):88-94, 1997.

Wozniak, K.; Czechowska, A. \& Blasiak, J. Cisplatin-evoked DNA fragmentation in normal and cancer cells and its modulation by free radical scavengers and the tyrosine kinase inhibitor STI571. Chem. Biol. Interact., 147(3):309-18, 2004.

Yeoman, R. R.; Jones,W. D. \& Rizk, B. M. Evidence for nitric oxide regulation of hamster sperm hyperactivation. J. Androl., 19(1):58-64, 1998.

Yun, J. W.; Shin, E. S.; Cho, S. Y.; Kim, S. H.; Kim, C. W.; Lee, T. R. \& Kim, B. H. The effects of BADGE and caffeine on the time-course response of adiponectin and lipid oxidative enzymes in high fat diet-fed C57BL/6J mice: correlation with reduced adiposity and steatosis. Exp. Anim., 57(5):461-9, 2008.

Zare, Z.; Eimani, H.; Mohammadi, M.; Mofid, M. \& Dashtnavard, $\mathrm{H}$. The effect of orally administered l-carnitine on testis tissue, sperm parameters and daily sperm production in adult mice. Yakhteh Med. J., 11(4):382-9, 2010.

\author{
Correspondence to: \\ Zahra Keshtman \\ Department of Biology \\ Science and Research Branch \\ Islamic Azad University \\ Tehran \\ IRAN
}

Email: zkeshtmand2001@yahoo.com

Received: 02-12-2013

Accepted: 14-01-2014 